Article

\title{
Optimization of a novel Hybrid Wind Bio Battery Solar Photovoltaic System Integrated with Phase Change Material
}

\author{
Vijay Mudgal ${ }^{1,+}\left(\mathbb{D}\right.$, Preeti Singh ${ }^{2, \dagger}$, Sourav Khanna ${ }^{3, *+}$, Chandan Pandey $^{4}$, Victor Becerra ${ }^{3}$, \\ Tapas K. Mallick ${ }^{5}$ and K. S. Reddy ${ }^{1}$ \\ 1 Heat Transfer and Thermal Power Laboratory, Department of Mechanical Engineering, Indian Institute of \\ Technology Madras, Chennai 600036, India; er.vijaymudgal@gmail.com (V.M.); ksreddy@iitm.ac.in (K.S.R.) \\ 2 Simulate Learning Solutions Pvt. Ltd., Indian Institute of Technology Kanpur, Kanpur 208016, India; \\ presingh16@gmail.com \\ 3 School of Energy and Electronic Engineering, University of Portsmouth, Portsmouth PO1 3DJ, UK; \\ victor.becerra@port.ac.uk \\ 4 Academy of Scientific and Innovative Research, Ghaziabad 201002, India; chandan@acsir.res.in \\ 5 Environment and Sustainability Institute, Penryn Campus, University of Exeter, Penryn TR10 9FE, UK; \\ T.K.Mallick@exeter.ac.uk \\ * Correspondence: sourav.khanna1@gmail.com \\ + These authors are first authors.
}

Citation: Mudgal, V.; Singh, P.; Khanna, S.; Pandey, C.; Becerra, V.; Mallick, T.K.; Reddy, K.S.

Optimization of a novel Hybrid Wind Bio Battery Solar Photovoltaic System Integrated with Phase Change Material. Energies 2021, 14, 6373. https://doi.org/10.3390/en14196373

Academic Editor: Carlo Renno

Received: 4 September 2021

Accepted: 30 September 2021

Published: 5 October 2021

Publisher's Note: MDPI stays neutral with regard to jurisdictional claims in published maps and institutional affiliations.

Copyright: (c) 2021 by the authors. Licensee MDPI, Basel, Switzerland. This article is an open access article distributed under the terms and conditions of the Creative Commons Attribution (CC BY) license (https:/ / creativecommons.org/licenses/by/ $4.0 /)$.

\begin{abstract}
The intermittent nature of renewable sources, such as solar and wind, leads to the need for a hybrid renewable energy system (HRES) that can provide uninterrupted and reliable energy to a remote and off-grid location with the use of a biogas generator and battery. In the present study, conventional PV panels have been integrated with phase change material (PCM) for power enhancement. In addition, various configurations (i. PV-Wind-Battery system, ii. PV-PCM-WindBattery, iii. PV-Wind-Biogas-Battery and iv. PV-PCM-Wind-Biogas-Battery) have been compared for the hot and humid climatic location of Chennai, India. Optimization has been carried out to minimize the cost of energy and the net present cost has also been computed. It has been found that the integration of PCM with the PV-Wind-Biogas-Battery-based off-grid system results in savings of USD 0.22 million in terms of net present cost and reduces the cost of energy from USD $0.099 / \mathrm{kWh}$ to USD 0.094/kWh. Similarly, for another off-grid HRES configuration of PV-Wind-Battery, the integration of PCM results in savings of USD 0.17 million, and reduces the cost of energy from USD $0.12 / \mathrm{kWh}$ to USD $0.105 / \mathrm{kWh}$.
\end{abstract}

Keywords: hybrid renewable energy system; solar photovoltaics; wind; battery; phase change material; optimization; net present cost; cost of energy

\section{Introduction}

The availability of energy plays a very important role in the economic growth and sustainable development of a society and nation. Around $10 \%$ of the world's population (789 million people), especially in remote areas, live without electricity [1]. Some of the reasons behind this include the high financial cost of the extension of a grid network to such areas, low population density, and several other cultural and social aspects. Most of the people in these regions depend on fossil fuel and locally available traditional fuels, such as wood and animal waste, to meet their energy demand, due to its easy availability. However, there are several problems associated with using fossil fuel, such as high variability in the prices, environmental degradation, and health issues. One of the solutions to overcome the drawbacks of fossil fuel and provide clean and easy electricity in these regions is using available renewable energy sources in that region [2]. This also results in economic development, an improved ecological balance and human development [3]. However, the intermittent and unpredicted power output of renewable sources results in a nonviable power supply and creates the need for a methodology for obtaining reliable energy 
from renewable energy sources. For an uninterruptible and viable power supply, various energy sources can be integrated to meet the electricity demand. Such systems are called hybrid renewable energy systems (HRESs), and usually consist of two or more renewable energy sources. Some of the advantages of HRESs include (i) the optimum utilization of renewable sources, (ii) improved controllability, (iii) increased load matching and (iv) the lower operational cost.

Different techniques have been developed and used by researchers to find the most appropriate size for a HRES. Tito et al. [4] suggested that the configuration of the HRES can be considered as optimized if it can minimize the overall system cost or the cost of energy with no unmet demand left over for all the classified socio-demographic load profiles of the site. Jamshidi et al. [5] estimated the optimal size of a Wind-PV-Diesel generator-based HRES using polynomial regression and support vector regression models. Alberizzi et al. [6] used a mixed Integer Linear Programming (MILP)-based optimization algorithm to find the optimal size of an HRES for a place located in South Tyrol, Italy. Martin-Arroyo et al. [7] investigated a stand-alone PV-Wind-based hybrid system using the smart spinning reverse management method. Similarly, Das et al. [8] used metaheuristic optimization techniques to find the optimal economical configuration to meet the electrical demand of a radio transmitter station in India. The results show that the optimal configuration includes a $69.2 \mathrm{~kW}$ PV panel, a $16 \mathrm{~kW}$ biogas generator, a converter size of $30 \mathrm{~kW}, 21$ battery bank units, and an upper reservoir volume of $2081.5 \mathrm{~m}^{3}$, with a total net present cost (NPC) of USD 0.813 million. Rezzouk and Mellit [9] carried out the techno-economic feasibility and sensitivity analysis of a PV-Diesel-Battery-operated HRES, with the penetration of PV varying from $0 \%$ to $100 \%$. From the results, it can be observed that system stability and optimum performance can be achieved with $25 \% \mathrm{PV}$ penetration. A sensitivity analysis showed that global radiation has a significant effect on the NPC and CoE of the system. Rahman et al. [10] showed that biogas and solar systems can be integrated to develop a hybrid energy system that can meet both electrical load and thermal (cooking) demands, and can efficiently replace conventional facilities. The results also show that monetary savings worth USD 309 to 412 per year can be achieved by using the proposed hybrid renewable energy system. Considering climate diversity and the energy efficiency of buildings, Mokhtara et al. [11] investigated the optimal sizing and mapping of hybrid renewable energy systems for an off-grid building at seven different locations in Algeria. The results show that climate zone and the energy performance of the building have significant effects on the optimal sizing of the HRES. The study makes recommendations related to efficient energy management between energy sources, stored energy and load demand for the optimization of the overall HRES. Baruah et al. [12] carried out techno-economic feasibility analyses of an HRES for the academic township in Sikkim, India, using HOMER. The results show that the optimum system is a PV-Wind-Biogas-Syngas-HydrokineticBattery-based system with an LCOE of USD 0.095/kWh. Al-bonsrulah et al. [13] carried out an analysis of a hybrid system for the Bahr Al-Najaf region. The results show that the energy contributions of fuel cell, wind turbine and PV are 4.38\%, 26.3\% and 69.3\%, respectively. Katsivelakis et al. [14] performed a techno-economic analysis of a hybrid renewable energy system on Donoussa Island, Greece, by varying the contributions $(20 \%$, $50 \%$ and $100 \%$ ) of renewable energy resources. The results show that with a $50 \%$ renewable energy contribution, a system can be obtained with $0 \%$ excess energy, an NPC of EUR 4,031,102.3 and a COE of EUR 0.2401/kWh. Kanase-Patil et al. [15] showed that an HRES with micro hydropower, biomass, biogas, solar energy, wind and energy plantation, with individual contributions of $44.99 \%, 30.07 \%, 5.19 \%, 4.16 \%, 1.27 \%$ and $12.33 \%$, respectively, can provide for the electrical and cooking needs of seven off-grid villages in Uttarakhand, India. The results also showed that the optimal HRES system had 0.95 energy index ratio, at the optimized cost of Rs 19.44 lacs and a COE of Rs 3.36 per unit.

Elavarasan et al. [16] carried out a study on the demand-side management of three different configurations of energy source, considering user satisfaction. The analysis showed that, overall, the traffic in the load can be reduced significantly by reductions in summer 
and winter peak load demands of $6.33 \%$ and $11.5 \%$, respectively. Kumar et al. [17] carried out a techno-economic and environmental study of a residential community in South India, considering the SDG7 goals by integrating different system configurations of a photovoltaic/wind turbine/diesel generator/battery energy storage system (PV/WT/DG/BESS). The results show that a hybrid renewable energy system with PV + DG + BESS is the most cost-effective configuration for the location of the study. Li et al. [18] carried out a technoeconomic feasibility study of a hybrid renewable system used to meet the load demand of a house in Urumqi, China, using different configurations of energy source. The result shows that the total net present cost (NPC) of the system can be reduced by $9 \%$ and $11 \%$ compared with a PV/battery and wind/battery power system if a hybrid system is used employing PV/wind/battery. The sensitivity study performed by the authors also shows that the total PV module generation of a hybrid system combined with a tracking system is greater than that of a system with an optimized PV module tilt angle.

Wu et al. [19] carried out the multi-objective optimization of an HRES integrating biomass CHP, PV and a heat storage system, considering economic and environmental emissions. The result shows that the optimized system with percentage contributions from CHP, PV and grid of $51.22 \%, 1.54 \%$ and $47.24 \%$, respectively, can facilitate a tradeoff between economic factors and emissions. Suleman et al. [20] developed an HRES employing solar and geothermal energy for multigeneration applications. The result shows that by combing these two energy sources, the overall energy and exergy efficiency of the system can reach $54.7 \%$ and $76.4 \%$, respectively. Chang et al. [21] studied a biohydrogen-based renewable system (BHIRES), which integrates the hydrogen generation of biomass fermentation, renewable energy power generation, and electrolysis, for hydrogen production and its further storage, and uses fuel cells for heat and power generation. The analysis showed that the BHIRES is cost-effective as compared to wind/PV/hydrogen, and reduces the cost of energy of the system by $9.6 \%$ from USD $1.005 \mathrm{kWh}$ to USD $0.908 \mathrm{kWh}$. The result also shows that the BHIRES system reduces the final cost of the system by $11.6 \%$ as compared to a wind/PV/hydrogen system.

The experiment conducted by Karthick et al. [22] on an integrated PV-PCM system at Kovilpatti, Tamil Nadu, India, using glauber salt $\left(\mathrm{Na}_{2} \mathrm{SO}_{4} \cdot 10 \mathrm{H}_{2} \mathrm{O}\right)$ as the $\mathrm{PCM}$, showed that the electrical efficiency of the PV panel was increased by $10 \%$ due to a reduction in its operating temperature by $8{ }^{\circ} \mathrm{C}$. Stropnik and Stritih [23] showed that, with PCM, the surface temperature of the PV panel can be lowered by a maximum of $35.6^{\circ} \mathrm{C}$, resulting in $9.2 \%$ additional power compared to a conventional PV panel. Khanna et al. [24] analyzed a finned PCM integrated PV panel, showing that the power produced by the PV panel in a warmer climate increases in the range of $10.1 \%$ to $12.1 \%$, and in colder climates it increases in the range of $5.4 \%$ to $6.7 \%$, as compared to the reference PV panel.

From the literature review, it can be observed that several researchers have optimized a hybrid renewable energy system using different technologies and methodologies. However, no work has been found in the literature where a phase change material has been integrated with a PV and hybrid renewable energy system. Phase change materials have the ability to cool down the PV [25] and store huge amount of energy in a latent form, consequently increasing the PV electrical efficiency [26]. The present study investigates how the integration of a phase change material with a PV panel will affect the optimization of the HRES, which thus has the potential to reduce the cost of energy. The mathematical modeling and optimization of the system have been carried out.

\section{Description of the Proposed System}

In order to analyze the effects of different components, such as the PV, wind turbine, PCM, biogas and battery, on the overall performance and cost of the hybrid renewable energy system, four different configurations have been considered, as follows:

(i) Conf-1-PV-Wind-Battery system;

(ii) Conf-2-PV-PCM-Wind-Battery system;

(iii) Conf-3-PV-Wind-Biogas-Battery system; 
(iv) Conf-4-PV-PCM-Wind-Biogas-Battery system.

The PV panel, wind turbine and battery bank are connected to the DC bus, whereas the biogas generator and electric load are connected to the AC bus. To maintain the flow of energy between the components of the HRES, a converter is used, which converts an alternating current $(\mathrm{AC})$ to a direct current (DC), or vice versa. The control panel is the heart of the whole system, and it controls the flow of energy between the components. Figure 1 shows the schematic representation of the proposed HRES.

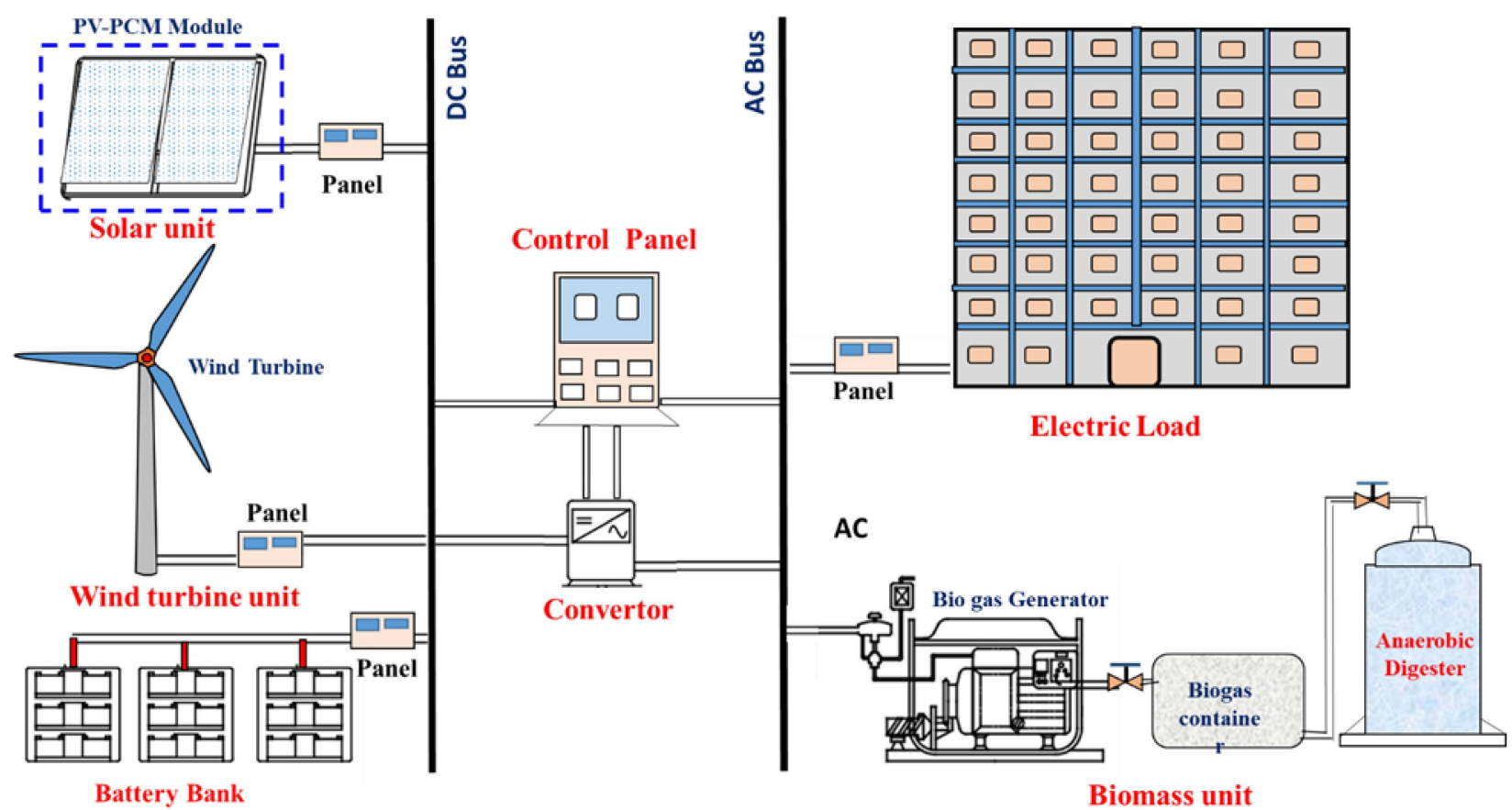

Figure 1. System representation of Hybrid renewable energy system.

\section{Description, Mathematical Modeling and Specification of System Components}

\subsection{Wind Energy System}

A wind turbine is a device that converts the kinetic energy of wind into electrical energy. The power output of the wind turbine depends upon various factors, such as the turbine's size, the wind speed and the height of the rotor, and is given by Equation (1) [27]

$$
P_{w}=\left\{\begin{array}{c}
a V^{3}(t)-b P_{R} V_{c i}<V<V_{r} \\
P_{R} V_{r}<V<V_{c o} \\
0 \text { otherwise }
\end{array}\right.
$$

where $a$ and $b$ are given by $a=\frac{P_{R}}{\left(V_{r}^{3}-V_{c i}^{3}\right)}$ and $b=\frac{V_{c i}^{3}}{\left(V_{r}^{3}-V_{c i}^{3}\right)}, P_{R}$ is the rated power of the turbine (W), $V_{c i}$ is the cut-in wind speed, $V_{r}$ is the rated wind speed and $V_{c o}$ is the cut-out wind speed measured in $\mathrm{ms}^{-1}$.

The output power of the wind turbine at different heights can be calculated by assessing wind speed at the reference height. Equation (2) is used to calculate wind speed at different heights

$$
V_{h}=V_{r e f}\left(\frac{H}{H_{r e f}}\right)^{\alpha}
$$

where $V_{h}$ and $V_{r e f}$ are wind speed $\left(\mathrm{ms}^{-1}\right)$ at height $\mathrm{H}(\mathrm{m})$ and at reference height $H_{\text {ref }}(\mathrm{m})$, respectively, and $\alpha$ is the power law coefficient. Figure 2 shows the wind speed at the IIT Madras, Chennai, India, for the whole year, and Table 1 shows the specifications. 


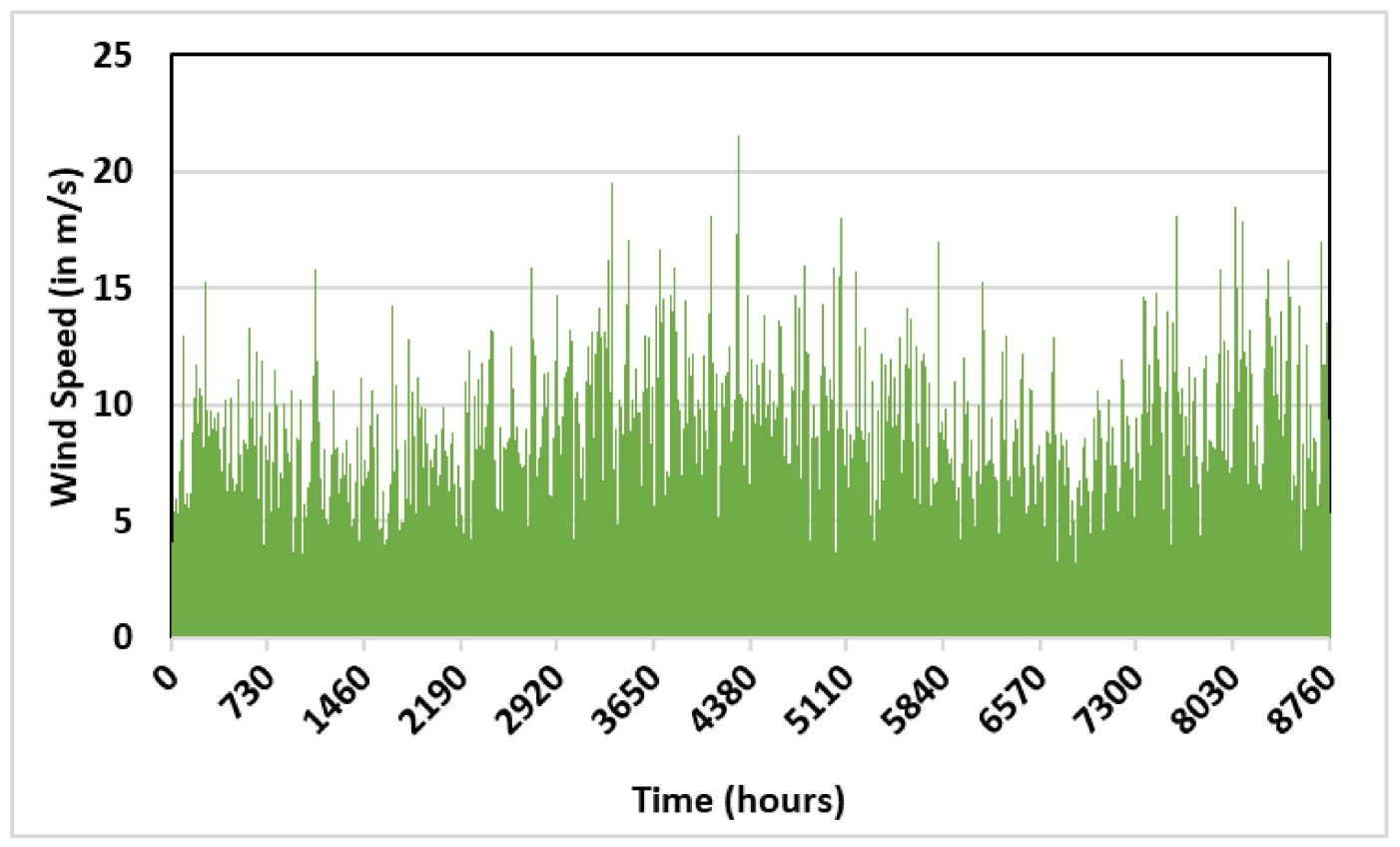

Figure 2. Velocity of wind at the location.

Table 1. Specifications of the wind turbine [28].

\begin{tabular}{ccc}
\hline Parameter & Unit & Value \\
\hline$P r$ & $\mathrm{~kW}$ & 3 \\
$V r$ & $\mathrm{~m} / \mathrm{s}$ & 12 \\
$V c i$ & $\mathrm{~m} / \mathrm{s}$ & 3.1 \\
$V c o$ & $\mathrm{~m} / \mathrm{s}$ & 24 \\
Rated voltage & $\mathrm{V}$ & 240 \\
Rotor diameter & $\mathrm{m}$ & 4.5 \\
Swept area & $\mathrm{m}^{2}$ & 15.1 \\
\hline
\end{tabular}

\subsection{PV System}

The PV module is a device that converts solar irradiation into electrical energy. The power output of a solar PV system depends upon several factors, such as the solar irradiance on the PV $\left(G_{I}\right)$, the area of a panel $(A)$, the number of panels $(N)$, the operating temperature of the cell $\left(T_{c}\right)$, the efficiency at STC $\left(\eta_{0}\right)$ and the degradation factor $\left(d_{P V}\right)$. Maximum energy is obtained from the PV panel when it operates in MPPT mode. The power output of the PV panel is given by Equation (3) [29].

$$
P_{P V}=\eta_{o} d_{P V}\left[1+\beta_{c}\left(T_{c}-25\right)+\gamma_{c} \ln \left(\frac{G_{I}}{1000}\right)\right] G_{I} A N
$$

Table 2 illustrates the specifications of the PV panel used for the present study. Figure 3 shows solar radiation at the IIT Madras, Chennai for the complete year. 
Table 2. Specification of conventional photovoltaic panel.

\begin{tabular}{ccc}
\hline Parameter & Unit & Value \\
\hline$P_{\max }$ & $\mathrm{W}$ & 250 \\
$V_{o c}$ & $\mathrm{~V}$ & 37.9 \\
$I_{S c}$ & $\mathrm{~A}$ & 8.59 \\
$V_{@ P \max }$ & $\mathrm{V}$ & 30.94 \\
$I_{@ P \max }$ & $\mathrm{A}$ & 8.08 \\
$F F$ & $\%$ & 76.11 \\
$\eta_{0}$ at $S T C$ & $\%$ & 15.9 \\
\hline
\end{tabular}

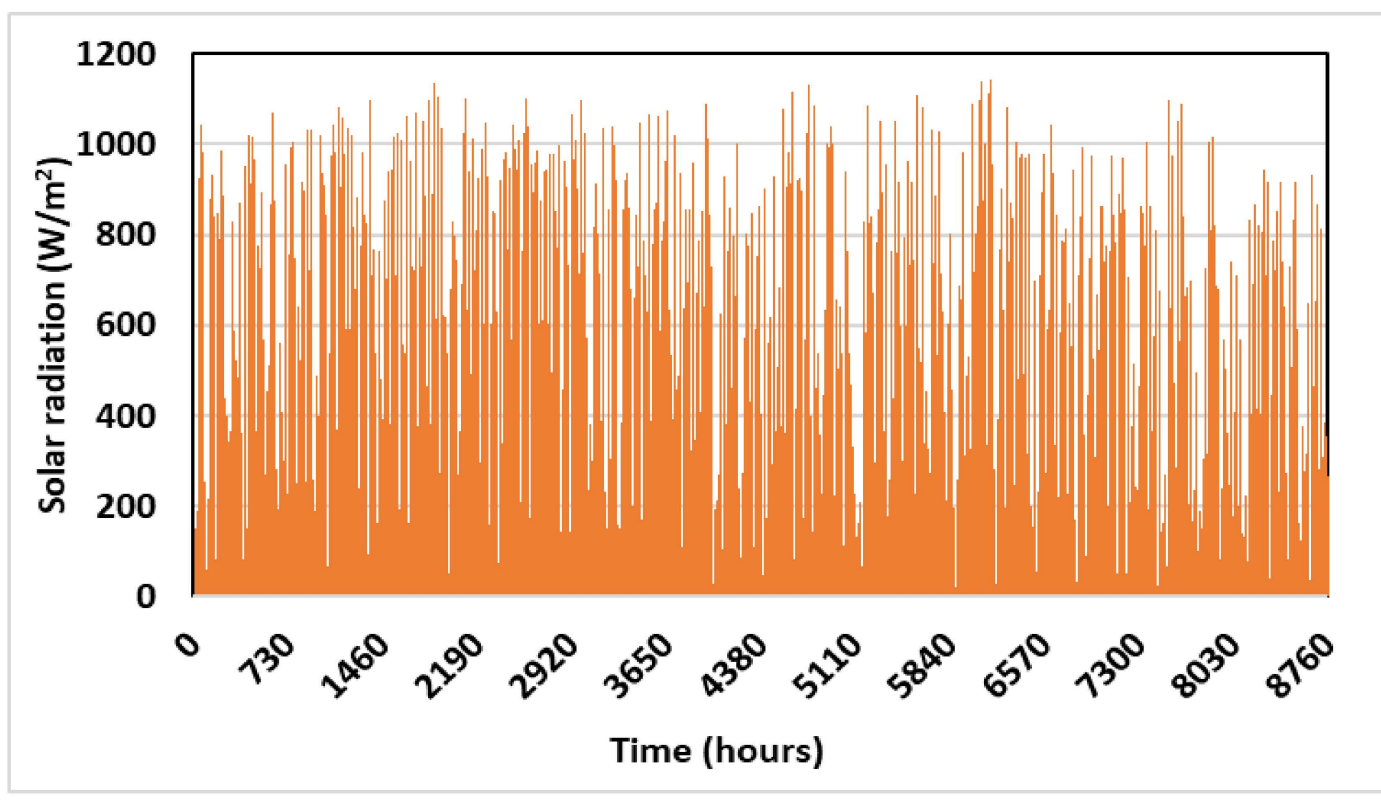

Figure 3. Solar radiation at the location.

\subsection{Phase Change Material}

Phase change materials can store/release huge amounts of heat during phase transition. This property of the PCM makes it suitable for various heating and cooling applications, and also suitable for integration with renewable resources for efficient system operation. Compared to a sensible heat storage system, the PCM-based latent heat storage system has a much higher ability to store or release thermal energy [30,31], which can be seen in the temperature vs. energy profile of the phase change material (Figure 4). The energy Profile of sensible material with respect to temperature is $\mathrm{OAB}$ whereas energy profile of phase change material with respect to temperature is OACD as shown in Figure 4. 


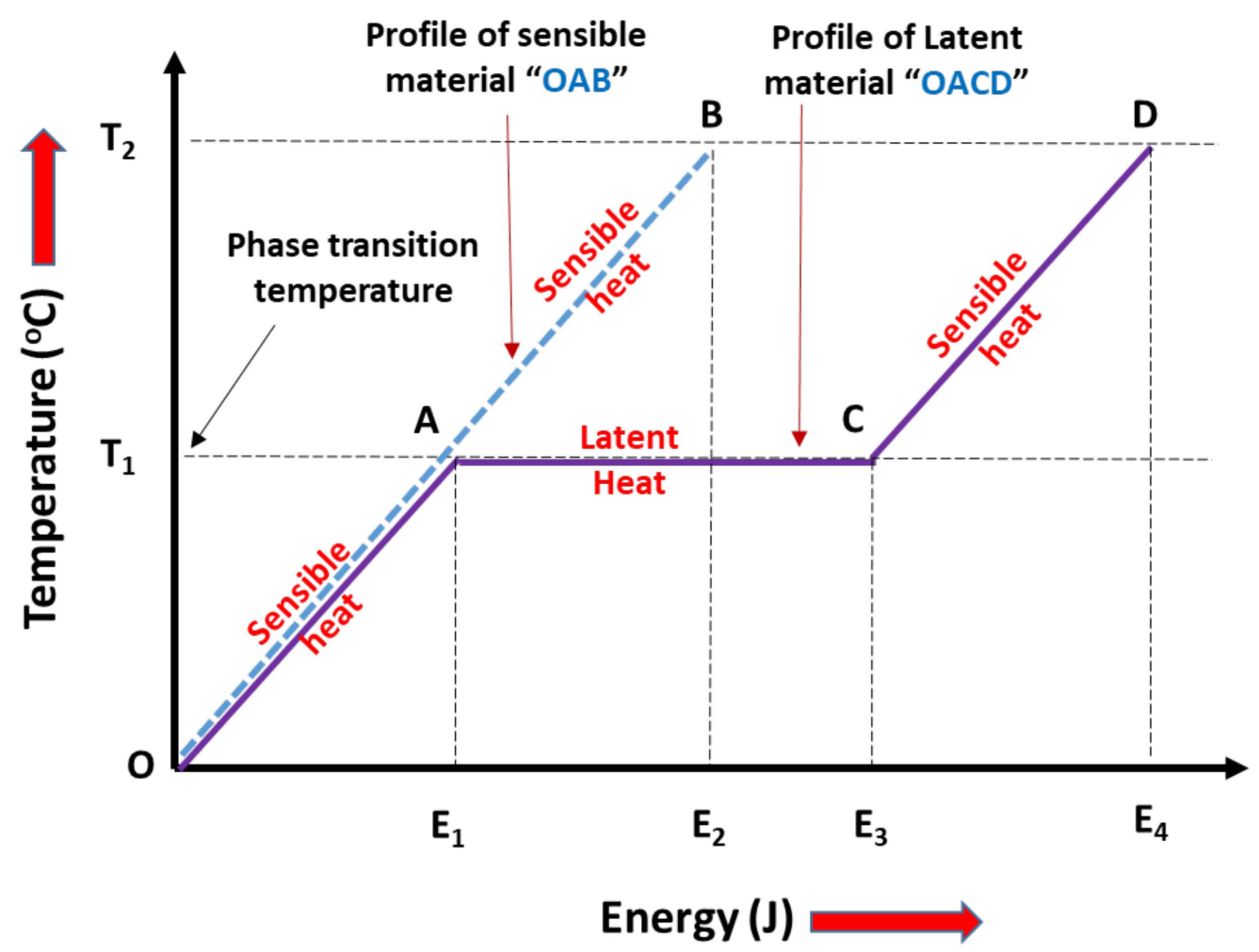

Figure 4. Temperature vs. energy profile of sensible and phase change material (latent).

\subsection{PV-PCM System}

A PV-PCM is an integrated system in which a phase change material is attached at the back of the PV panel, as shown in Figure 5. The phase change material absorbs the heat of the PV module and thereby regulates the operating temperature of the PV [32]. The lower operating temperature of the solar cells increases the electrical efficiency $[33,34]$ and prevents the degradation of the panel, which improves the overall effective life of the panel. It has been reported that PCM integration can improve the electrical efficiency of the system significantly for hot climates as compared to cold climates [35]. Experiments conducted by Japs et al. [36] at the University of Paderborn show that a PV-PCM-integrated system can generate $3.05 \%$ more electricity compared to a conventional panel. The heat storage capacity of the PCM depends upon the melting temperature of the PCM and its latent heat capacity. Calcium chloride hexahydrate with a melting point of around $30{ }^{\circ} \mathrm{C}$ and a latent heat capacity of $191 \mathrm{~kJ} / \mathrm{kg}$ is used as the PCM, and its thermophysical properties are listed in Table 3. The mathematical model presented in the previous work [35] has been used to evaluate the performance of the PV-PCM system.

Table 3. Thermophysical properties of the PCM (calcium chloride hexahydrate $\mathrm{CaCl}_{2} \cdot 6 \mathrm{H}_{2} \mathrm{O}$ ).

\begin{tabular}{ccc}
\hline Thermophysical Properties & Unit & Specification \\
\hline Melting point & ${ }^{\circ} \mathrm{C}$ & 30 \\
Heat of fusion & $\mathrm{kJ} \mathrm{kg}^{-1}$ & 191 \\
Thermal conductivity & $\mathrm{W} \mathrm{m}^{-1} \mathrm{C}^{-1}$ & 1.08 \\
Density & $\mathrm{kg}^{-1}$ & 1.71 \\
Specific heat capacity & $\mathrm{kJ} \mathrm{kg}^{-1} \mathrm{~K}^{-1}$ & 1.4 \\
Kinematic viscosity & $\mathrm{m}^{2} \mathrm{~s}^{-1}$ & $1.84 \times 10^{-3}$ \\
Thermal expansion coefficient & $\mathrm{K}^{-1}$ & $5.0 \times 10^{-4}$ \\
\hline
\end{tabular}




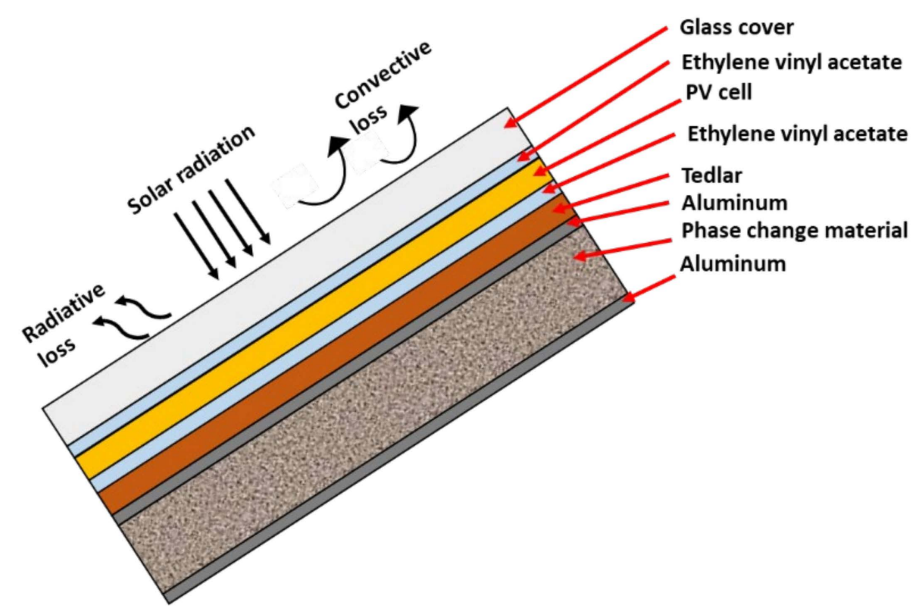

Figure 5. Integrated PV-PCM system.

\subsection{Biogas Generator}

A biogas generator is a device that uses biogas as fuel and converts it into electrical energy. Biogas is a mixture of gases produced by the decomposition of organic waste in an anaerobic environment. The power output from the biogas generator is given by Equation (4) [28].

$$
P_{\text {Bio }}=\frac{\text { Annual Biomass available } * \mathrm{CV}_{\text {Bio }} * \eta_{\text {Bio }}}{365 * \text { operating hours in a day } * 3600}
$$

The specifications of the generator are presented in the Table 4 [37].

Table 4. Specifications of generator [36].

\begin{tabular}{cc}
\hline Parameter & Specification \\
\hline Model & ELEMAX SH5300EX Generator \\
Engine type & 4-stroke, single cylinder, side valve, Spark \\
ignition engine \\
Ignition system & Transistorized coil ignition (TCI) \\
Rated power & $6.3 \mathrm{~kW} \mathrm{@} \mathrm{3600} \mathrm{rpm}$ \\
Generator AC output & $5.3 \mathrm{kVA} @ 220 \mathrm{~V}, 60 \mathrm{~Hz}$ \\
Cooling system & Forced air cooling \\
\hline
\end{tabular}

\subsection{Battery Bank Energy Storage System}

The charging of the battery takes place when the power generated by the PV and wind turbine is more than the demand. When the power produced by the PV and wind is less than the demand, the battery bank acts as a secondary power source. The battery bank's capacity is selected based on the power required for a day, the battery efficiency, and the energy demand. The characterization of the battery's charge status and discharge status is determined by the state of charge (SOC). The $S O C$ is defined as the ratio of current capacity to the nominal capacity of the battery. The battery is fully charged when the SOC is 1 and battery is empty when the SOC is 0 . The instantaneous SOC of a battery can be calculated by Equation (5) [38].

$$
\operatorname{SOC}(t)=\operatorname{SOC}(t-1) \cdot\left(1-\frac{\sigma \Delta t}{24}\right)+\left(\frac{I_{b a t}(t) \cdot \Delta t \cdot \eta_{b a t}}{C_{b a t}}\right)
$$

where $S O C(t)$ is the state of charge of the battery at time $t, \sigma$ is the battery self-discharge rate, $\mathrm{I}_{\text {bat }}$ is the battery current at time $t(A), \eta_{b a t}$ is the battery charge efficiency and $C_{b a t}$ is the capacity of the battery. 
The instantaneous battery current can be calculated by Equation (6).

$$
I_{\text {bat }}(t)=\frac{P_{p v / P C M}(t)+P_{\text {wind }}(t)-P_{\text {load }}(t)}{V_{\text {bat }}(t)}
$$

where $P_{p v / P C M}(t)$ is the instantaneous power generated by the $P V / P C M$ module, $P_{\text {wind }}(t)$ is the instantaneous power generated by the wind turbine, $P_{\text {load }}(t)$ is the instantaneous power demand and $V_{b a t}(t)$ is the terminal voltage of the battery. The capacity of the battery $C_{\text {bat }}$ is calculated by Equation (7) [39].

$$
C_{\text {bat }}=\left(E_{\text {Load }} A D\right) \eta_{\text {inv }} \eta_{b a t} D O D
$$

where $E_{\text {load }}$ is the total energy demand, $A D$ is the daily autonomy, $D O D$ is the depth of discharge of the battery, $\eta_{i n v}$ is the inventor efficiency, and $\eta_{b a t}$ is the battery efficiency.

\subsection{Converter System}

In the present system, the wind turbine, PV / PCM panel and battery bank are connected to the DC bus, whereas biogas generator and the electric load are connected to the $\mathrm{AC}$ bus. Therefore, a converter is required to convert $\mathrm{AC}$ to $\mathrm{DC}$, or vice versa, as per the requirement to maintain the flow of power between the HRES components. The converter consists of a rectifier and inverter assembly. The power output of the converter is given by the Equations (8) and (9):

$$
\begin{aligned}
P_{\text {inv }, \text { out }} & =\eta_{\text {inv }} P_{D C} \\
P_{\text {rec }, \text { out }} & =\eta_{\text {rec }} P_{A C}
\end{aligned}
$$

where $P_{\text {inv,out }}$ is the output power of the inverter, $\eta_{i n v}$ is the efficiency of the inverter, $P_{D C}$ is the $D C$ power input, $P_{\text {rec,out }}$ is the output power of the rectifier, $\eta_{\text {rec }}$ is the efficiency of the rectifier and $P_{A C}$ is the $A C$ power input.

\subsection{Load Profile}

For the present study, a hostel in IIT Madras, Chennai, India is assessed for its electric load. The electric load profile is the main influencing factor in the design and optimization of integrated hybrid energy systems. So, it is very important to know how load varies during weekdays and weekends in order for the hybrid system to achieve the maximum utilization of resources and minimum system costs. The electric loads considered for the present study are computers, fans, lights, electronic devices and machinery. The electric load profiles of the Hostel during weekdays and during weekends are shown in Figure 6a and Figure $6 \mathrm{~b}$ respectively. 


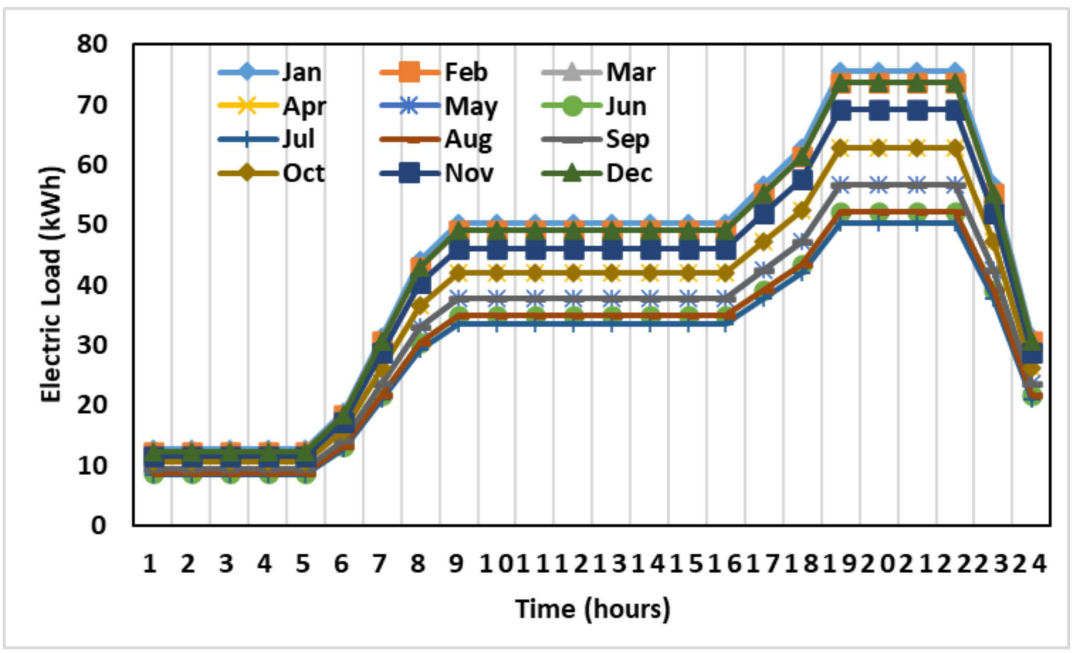

(a)

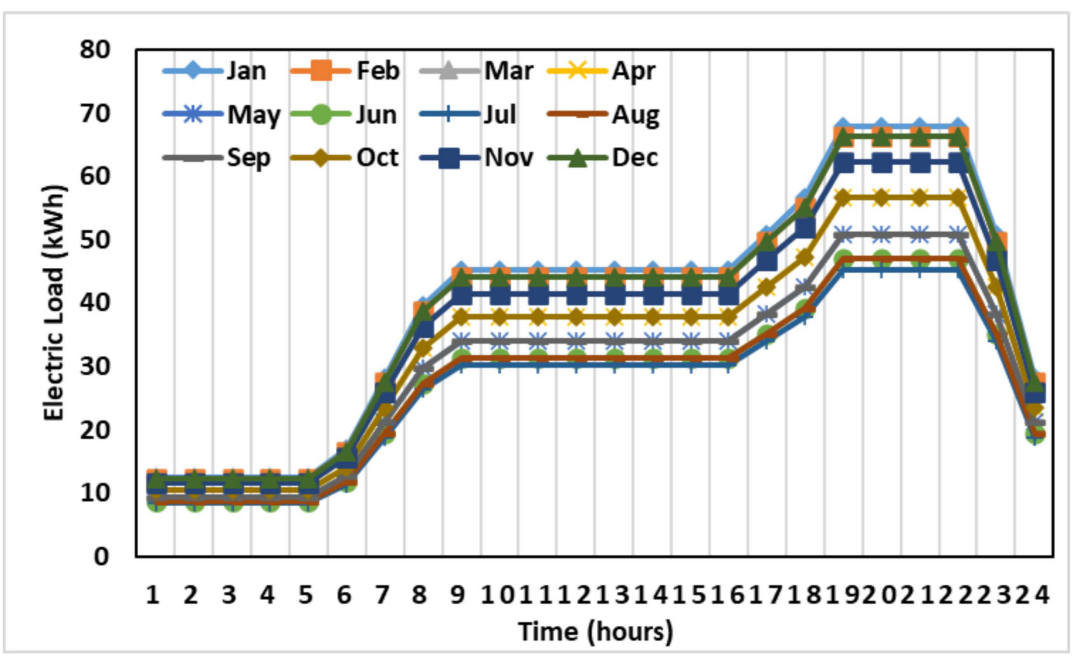

(b)

Figure 6. Electricity demand (a) during weekdays (b) during weekends.

\subsection{Constraints}

The optimization of the hybrid integrated system has been achieved considering different constraints, which are discussed as follows.

\subsubsection{Lower and Upper Limit of Energy Source}

In present study, the sizes of the PV-PCM, wind turbine, biogas generator and battery bank were varied to find the optimum levels to meet the electricity demand of the hostel at IIT Madras. The lower and upper limits of the PV-PCM, wind turbine, biogas generator and battery bank are given by the following Equation (10):

$$
\begin{aligned}
& 0 \leq N_{P V-P C M} \leq N_{P V-P C M}^{\operatorname{Max}} \\
& 0 \leq N_{W T} \leq N_{W T}^{M a x} \\
& 0 \leq N_{\text {Biogen }} \leq N_{\text {Biogen }}^{\text {Max }} \\
& 0 \leq N_{\text {Batt }} \leq N_{\text {Batt }}^{\text {Max }}
\end{aligned}
$$

where $N_{P V-P C M}, N_{W T}, N_{B i o g e n}$ and $N_{B a t t}$ are the capacities of the $P V-P C M$ panels, the wind turbine and the biogas generator, and the number of batteries, respectively. The capacity values of all the system components are considered as integer values. 


\subsubsection{Battery Bank Operational Constraint}

For the long life and effective functioning of the battery bank, it is important that the charging and discharging of the battery is within safe operational limits. The battery bank should not be overcharged or discharged below a limit. The operational constraints levied on the battery bank for effective and safe working are given by Equation (11):

$$
E_{\text {Battmin }} \leq E_{\text {Batt }}(t) \leq E_{\text {Battmax }}
$$

where $E_{\text {Battmin }}$ and $E_{\text {Battmax }}$ are, respectively, the maximum and minimum allowed energy values of the battery bank.

\subsubsection{Wind Turbine Operational Constraints}

The wind turbine power output depends on the wind speed. Only after the cut-in (threshold) wind speed is power generation possible from the wind turbine. Additionally, for safe operation, there is a cut-off wind speed after which the turbine is not operated. The operational wind speed constraint imposed on the wind turbine for effective power generation is given by Equation (12):

$$
V_{C i} \leq V(t) \leq V_{C o}
$$

\subsubsection{Power Reliability Constraints}

The integrated hybrid renewable energy sources must always be able to meet the load demand with zero percentage shortage. The loss of power supply probability (LPSP) is the power exerted by the HRES to meet load demand. The LPSP is given by Equation (13) [39],

$$
\operatorname{LPSP}=\frac{\sum_{t=1}^{8760} \operatorname{LPS}(t)}{\sum_{t=1}^{8760} E_{\operatorname{Dem}}(t)}
$$

Loss of power supply (LPS) at any time " $\mathrm{t}$ " can be calculated by Equation (14) [40]

$$
\operatorname{LPS}(t)=E_{\text {Dem }}(t)-E_{W T}(t)-E_{P V / P C M}(t)-E_{\text {Biogen }}(t)-E_{\text {Batt }}(t)
$$

\section{System Operation and Optimization}

\subsection{Control Strategy and Operation}

The operation of the hybrid renewable energy system is a priority-based interaction between different energy sources. The control algorithm mediates between electric load and the power output of the different energy sources. The control strategy operates with the following objectives:

(i) To maximize the utilization of energy from PV and wind energy sources;

(ii) To minimize the storage capacity and operation of the battery bank;

(iii) To minimize the operation of the biogas generator so as to reduce the emissions and the operation and maintenance cost.

\begin{tabular}{|c|c|c|c|c|}
\hline Component & Energy Availability & Constraint & Priority Level & Remarks \\
\hline PV & Sunny hours & Night time, cloudy sky & 1 & $\begin{array}{l}\text { Cheapest source of energy, no prime } \\
\text { mover, no emission, less maintenance }\end{array}$ \\
\hline Wind turbine & High wind speed & $\begin{array}{l}\text { Low and very high wind } \\
\text { speed }\end{array}$ & 2 & $\begin{array}{l}\text { Cheap source of energy, no emission, } \\
\text { regular maintenance cost }\end{array}$ \\
\hline Battery bank & $\begin{array}{l}\text { When SOC is more } \\
\text { than zero }\end{array}$ & $\begin{array}{l}\text { Overcharging and } \\
\text { discharging }\end{array}$ & 3 & $\begin{array}{c}\text { Stored renewable energy can be used, } \\
\text { no emission }\end{array}$ \\
\hline Biogas generator & Always available & $\begin{array}{l}\text { Over winding heating } \\
\text { limit }\end{array}$ & 4 & $\begin{array}{l}\text { Involves running cost and regular } \\
\text { maintenance cost due to prime mover } \\
\text { emission }\end{array}$ \\
\hline
\end{tabular}

Table 5.

The dispatch strategy of the HRES based on the priority of operation is described in

Table 5. Priority of operation of different energy sources. 


\subsection{Net Present Cost}

The net present cost (NPC) is the total present cost of the system (expense minus revenue) incurred over the lifetime of the project. NPC includes capital cost, operation and maintenance cost (O\&M), replacement cost, fuel cost and salvage cost. NPC is calculated using Equation (15) [41]

$$
N P C=\frac{C_{a n n}}{C R F\left(i, R_{p r o j}\right)}
$$

where $C_{a n n}$ is the annualized cost and $C R F$ is the capital recovery cost.

\subsection{Cost of Energy}

The cost of energy $(C O E)$ is the average net present cost of the generated electric energy. $C O E$ is calculated as the ratio of annualized cost $\left(C_{a n n}\right)$ to the total energy generated by the integrated system. COE includes capital cost, fuel cost, financing cost, and O\&M cost. $C O E$ is an important parameter for the optimization of the integrated renewable energy system. COE signifies the revenue per unit of electric unit sold to recover the investment and operation cost of the system. The COE is calculated using Equation (16),

$$
\operatorname{COE}=\frac{C_{a n n}}{E_{s e r}}
$$

where $C_{a n n}$ is the annualized cost and $E_{s e r}$ is the useful energy generated by the integrated system.

\subsection{Capital Recovery Factor}

The capital recovery factor $(C R F)$ signifies the return on invested capital over an investment's life span. It is the ratio of a constant annuity to the present value of receiving that annuity over the lifetime of a project. The $C R F$ is calculated by Equation (17),

$$
C R F=\frac{i(1+i)^{a n}}{(1+i)^{a n}-1}
$$

where $i$ is interest rate (\%) and an is annuity.

The economic data and operation life of different components of the HRES are listed

\begin{tabular}{|c|c|c|c|c|}
\hline Component & Capital Cost (in USD) & O\&M Cost (in USD) & $\begin{array}{l}\text { Replacement Cost } \\
\quad \text { (in USD) }\end{array}$ & Life \\
\hline Wind turbine & $934 / \mathrm{kW}$ & $50 / \mathrm{kW} /$ year & $934 / \mathrm{kW}$ & 25 years \\
\hline PV Panel & $300 / \mathrm{kW}$ & $20 / \mathrm{kW} /$ year & $300 / \mathrm{kW}$ & 25 years \\
\hline PV-PCM Panel & $400 / \mathrm{kW}$ & $25 / \mathrm{kW} /$ year & $400 / \mathrm{kW}$ & 25 years \\
\hline Solar inverter and control panel & $180 / \mathrm{kW}$ & $8 / \mathrm{kW} /$ year & $180 / \mathrm{kW}$ & 15 years \\
\hline Battery (200 Ah, $12 \mathrm{~V})$ & $150 /$ batt & 5/batt/year & $110 /$ batt & 5 years \\
\hline Biogas generator & $400 / \mathrm{kW}$ & $0.01 / \mathrm{kWh}$ & $300 / \mathrm{kW}$ & $20,000 \mathrm{~h}$ \\
\hline
\end{tabular}
in Table 6.

Table 6. Cost of various components of HRES.

\section{Results and Discussion}

In the present study, four configurations ((i) PV-Wind-Battery system, (ii) PV-PCMWind-Battery, (iii) PV-Wind-Biogas-Battery and (iv) PV-PCM-Wind-Biogas-Battery) have been compared. Optimization has been carried out to minimize the cost of energy and the net present cost has also been computed. It has been found that the optimum configuration of a PV-Wind-Battery system is the one with an $819 \mathrm{~kW} \mathrm{PV}$, a $321 \mathrm{~kW}$ wind turbine, $3957 \mathrm{Ah}$ battery storage and a $316 \mathrm{~kW}$ converter. After PCM integration, the optimum configuration is the one with a $781 \mathrm{~kW}$ PV-PCM, a $278 \mathrm{~kW}$ wind turbine, 3980 Ah battery storage and a $391 \mathrm{~kW}$ converter. Similarly, the optimum configuration for the PV-Wind-Biogas-Battery 
includes a $265 \mathrm{~kW} \mathrm{PV}$, a $228 \mathrm{~kW}$ wind turbine, a $420 \mathrm{~kW}$ biogas generator, 657 Ah battery storage and a $184 \mathrm{~kW}$ converter. After PCM integration, the optimum configuration is the one with a $224 \mathrm{~kW}$ PV-PCM, a $206 \mathrm{~kW}$ wind turbine, a $420 \mathrm{~kW}$ biogas generator, $633 \mathrm{Ah}$ battery storage and a $170 \mathrm{~kW}$ converter. The energy production and economic analysis are presented in the following subsections.

\subsection{Energy Analysis}

The monthly energy contributions of various energy sources for different configurations of the HRES are presented in Figures 7-10. It can be observed from Figures 7 and 8 (comparison between Conf-1 and Conf-2) that due to the integration of a PCM with the PV panel, the percentage contribution of the photovoltaics increased significantly. The total energy contribution of the photovoltaic increased from 1,217,961 kWh/year to 1,380,474, even when there was a reduction in the installed PV from $819 \mathrm{~kW}$ to $781 \mathrm{~kW}$. The penetration factor of PV also increased from $132 \%$ to $150 \%$. Similarly, it can be observed from Figures 9 and 10 (comparison between Conf-3 and Conf-4) that due to the integration of PCM with the PV panel, the percentage contribution of the photovoltaics increased significantly. The total energy contribution of the photovoltaic increased from $340,835 \mathrm{kWh} /$ year to $394,079 \mathrm{kWh} /$ year, even when there was a decrease in the installed PV from $265 \mathrm{~kW}$ to $224 \mathrm{~kW}$. The penetration factor of PV also increased from $37.1 \%$ to $42.8 \%$. A breakdown of the energy analysis of all the configurations of the hybrid renewable energy system is presented in Table 7.

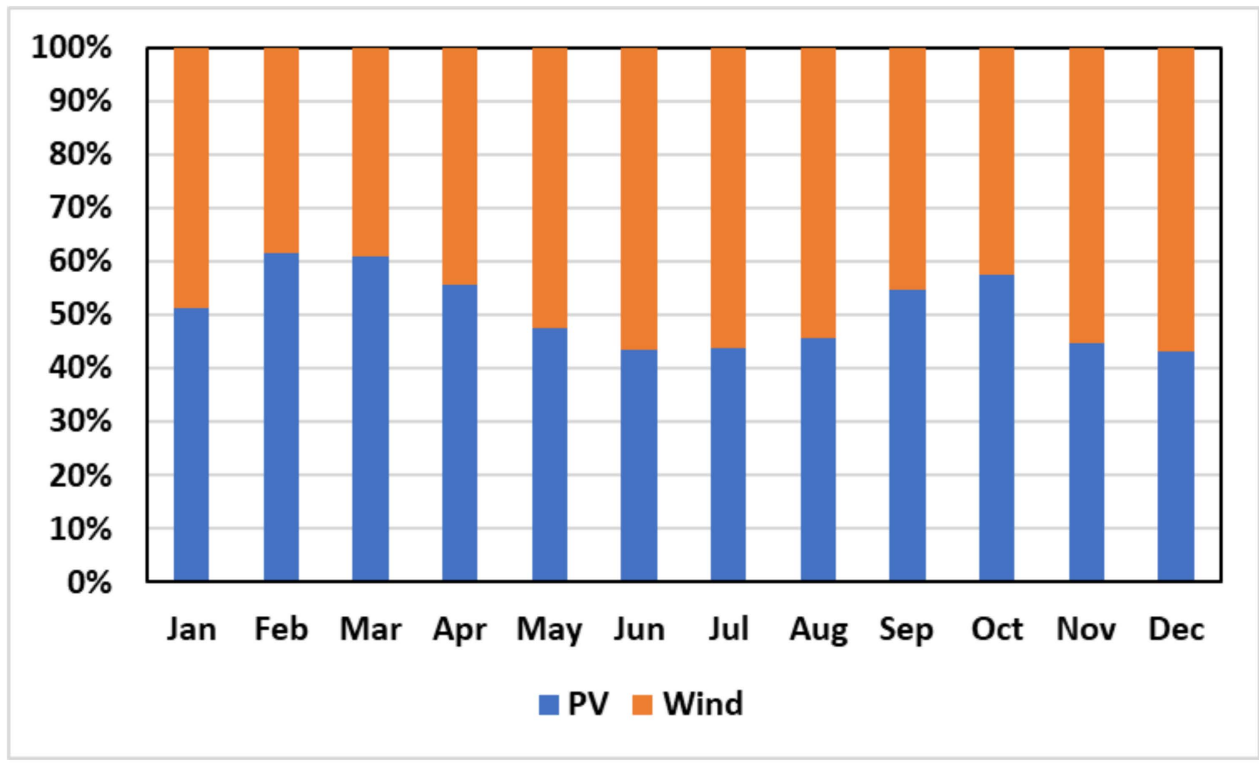

Figure 7. Monthly energy contribution of Conf-1. 


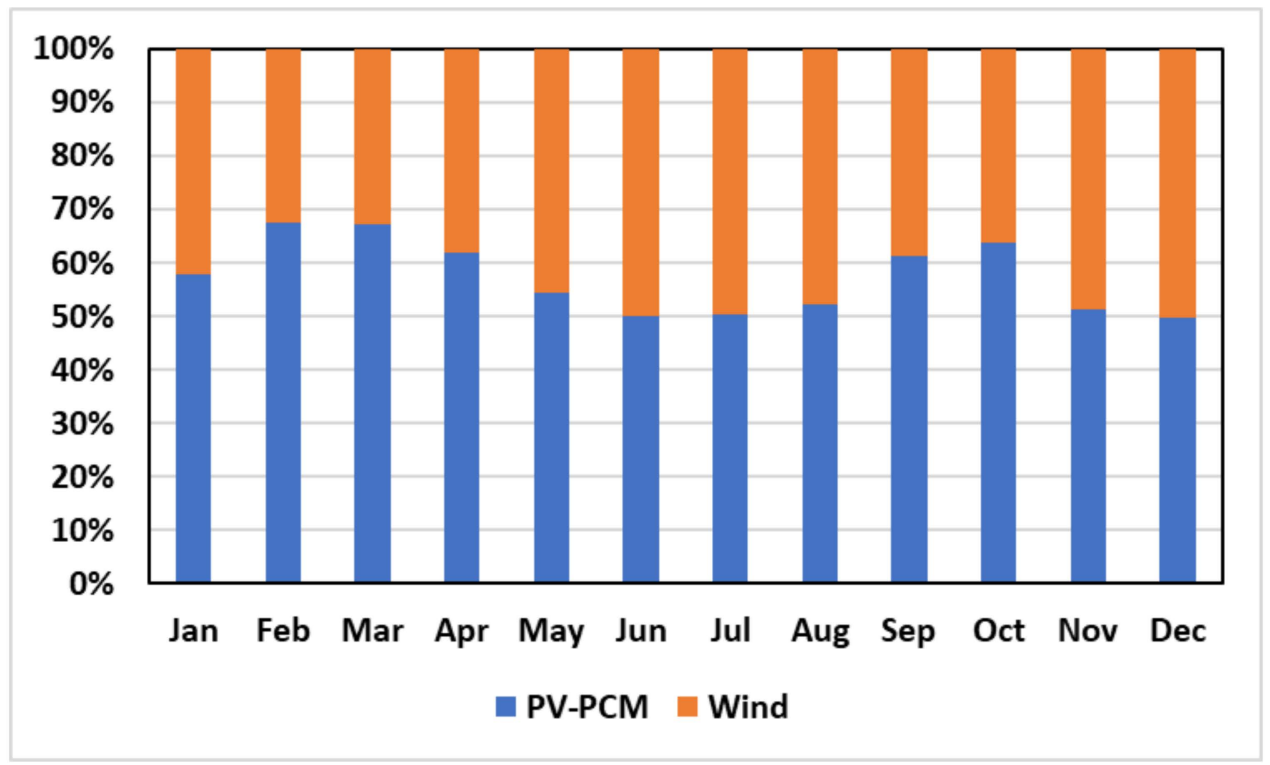

Figure 8. Monthly energy contribution of Conf-2.

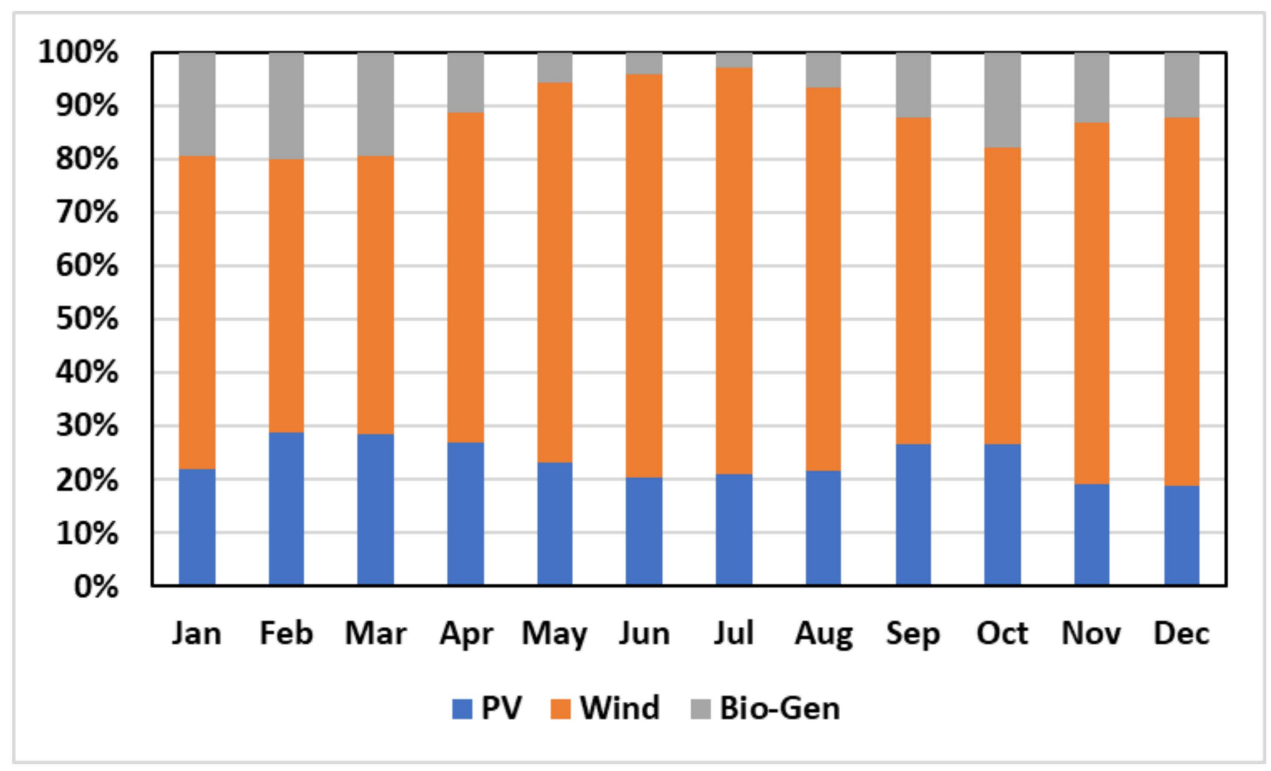

Figure 9. Monthly energy contribution of Conf-3. 


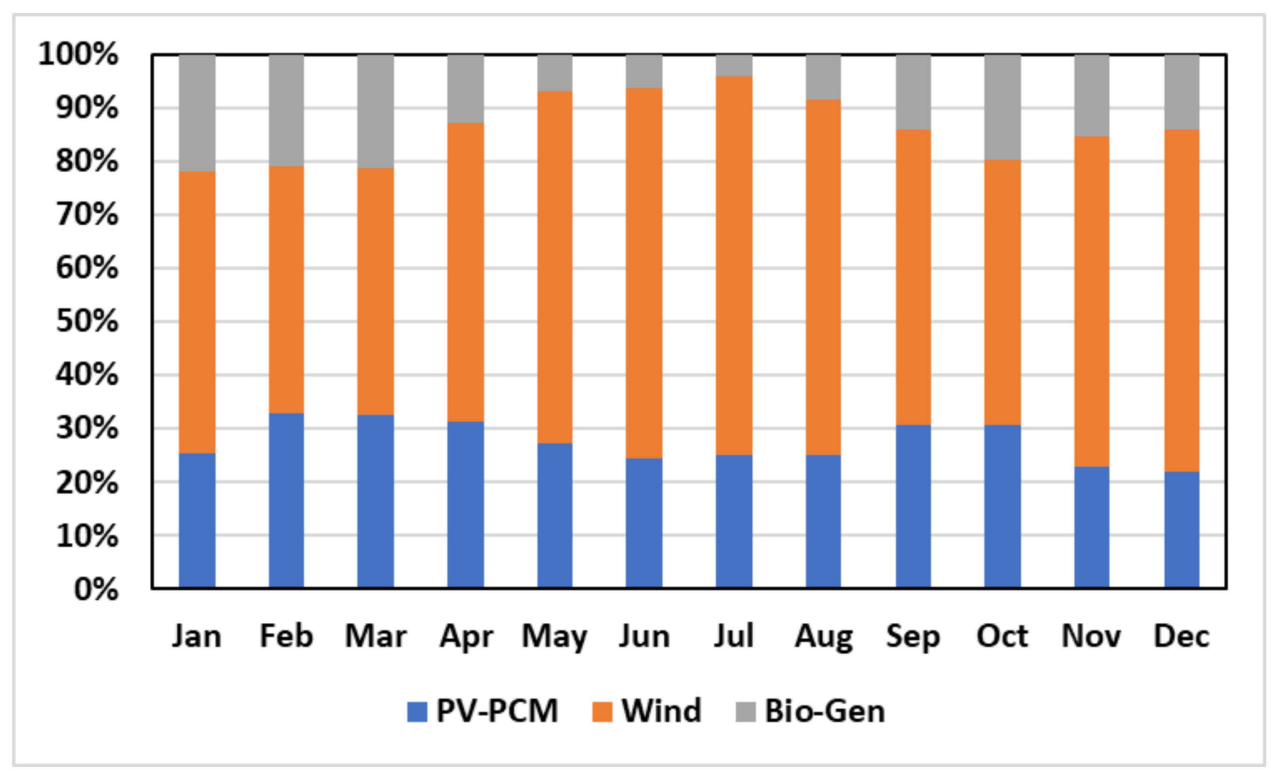

Figure 10. Monthly energy contribution of Conf- 4 .

Table 7. Energy analysis of hybrid energy system.

\begin{tabular}{|c|c|c|c|c|c|}
\hline Configuration & Component & $\begin{array}{c}\text { Capacity } \\
\text { Factor }(\%)\end{array}$ & $\begin{array}{c}\text { Penetration } \\
\text { Factor }(\%)\end{array}$ & $\underset{\text { Operation/y }}{\mathrm{H} \text { of }}$ & $\begin{array}{c}\text { Energy } \\
\text { Contribution } \\
(\mathrm{kWh} / \mathrm{y})\end{array}$ \\
\hline \multirow{4}{*}{ Conf-1 } & Wind turbine & 28.4 & 130 & 7564 & $1,198,517$ \\
\hline & Solar PV & 17 & 132 & 4373 & $1,217,961$ \\
\hline & Rectifier & 3.02 & - & 2347 & - \\
\hline & Inverter & 11.4 & - & 4268 & - \\
\hline \multirow{4}{*}{ Conf-2 } & Wind turbine & 28.4 & 113 & 7564 & $1,037,968$ \\
\hline & Solar PV-PCM & 17.3 & 150 & 4373 & $1,380,474$ \\
\hline & Rectifier & 2.29 & - & 2147 & - \\
\hline & Inverter & 10.1 & - & 4687 & - \\
\hline \multirow{5}{*}{ Conf-3 } & Wind turbine & 28.4 & 103 & 7564 & 944,626 \\
\hline & Solar PV & 17.3 & 37.1 & 4373 & 340,835 \\
\hline & Biogas gen & 4.71 & - & 1260 & 173,320 \\
\hline & Rectifier & 5.39 & - & 2674 & - \\
\hline & Inverter & 14.2 & - & 3962 & - \\
\hline \multirow{5}{*}{ Conf- 4} & Wind turbine & 28.4 & 92.6 & 7564 & 851,283 \\
\hline & Solar PV-PCM & 17 & 42.8 & 4373 & 394,079 \\
\hline & Biogas gen & 5.44 & - & 1477 & 200,266 \\
\hline & Rectifier & 4.36 & - & 2517 & - \\
\hline & Inverter & 13.2 & - & 4055 & - \\
\hline
\end{tabular}

\subsection{Economic Analysis}

The optimization of all the configurations of the HRES was carried out on the basis of the net present cost of the system, which includes the capital cost, operation and maintenance cost, fuel cost, and replacement cost minus the salvage cost of all components over the time period of 25 years. A breakdown of the net present cost of all the configurations of the hybrid renewable energy system is presented in Table 8. The NPCs of Conf-1, Conf-2, Conf-3 and Conf-4 are USD 2.50 million, USD 2.32 million, USD 1.65 million and USD 1.43 million, respectively. It can be observed that due to the efficiency enhancement of the PV panel using a phase change material, there was a reduction in the principal, operation and maintenance costs of the PV panel, thereby resulting in cost savings of USD 0.17 million between Conf- 1 and Conf- 2 and USD 0.22 between Conf- 3 and Conf- 4 . The cost of energy (CoE) of the HRES is also reduced due to the integration of PCM with the PV panel. The CoE values of Conf-1, Conf-2, Conf-3 and Conf- 4 are USD 0.12/kWh, USD 0.105/kWh, USD 0.099/kWh and USD 0.094/kWh, respectively. 
Table 8. Cost breakdown of net present cost of HRES system in different configurations.

\begin{tabular}{|c|c|c|c|c|c|c|c|}
\hline & Component & $\begin{array}{l}\text { Principal Cost } \\
\text { (in USD) }\end{array}$ & $\begin{array}{l}\text { O\&M Cost (in } \\
\text { USD) }\end{array}$ & $\begin{array}{l}\text { Replacement } \\
\text { Cost (in USD) }\end{array}$ & $\begin{array}{l}\text { Fuel Cost } \\
\text { (in USD) }\end{array}$ & $\begin{array}{l}\text { Salvage Cost } \\
\text { (in USD) }\end{array}$ & Total (USD) \\
\hline \multirow{5}{*}{ Conf-1 } & Wind turbine & 449,400 & 207,487 & 0 & 0 & 0 & 656,887 \\
\hline & PV & 286,506 & 264,558 & 0 & 0 & 0 & 551,064 \\
\hline & Converter and control panel & 56,957 & 32,725 & 24,165 & 0 & 4548 & 109,300 \\
\hline & Battery & 592,650 & 255,383 & 383,950 & 0 & 52,057 & $1,179,926$ \\
\hline & Complete HRES & $1,385,513$ & 760,152 & 408,116 & 0 & 56,605 & $2,497,177$ \\
\hline \multirow{5}{*}{ Conf-2 } & Wind turbine & 389,200 & 179,692 & 0 & 0 & 0 & 568,892 \\
\hline & PV-PCM & 234,300 & 194,120 & 0 & 0 & 0 & 428,420 \\
\hline & Converter and control panel & 70,377 & 40,413 & 29,842 & 0 & 5617 & 135,015 \\
\hline & Battery & 597,000 & 257,258 & 386,769 & 0 & 52,440 & $1,188,587$ \\
\hline & Complete HRES & $1,290,877$ & 671,483 & 416,611 & 0 & 58,057 & $2,320,914$ \\
\hline \multirow{6}{*}{ Conf-3 } & Wind turbine & 319,200 & 147,373 & 0 & 0 & 0 & 466,573 \\
\hline & PV & 92,700 & 85,599 & 0 & 0 & 0 & 178,299 \\
\hline & Converter and control panel & 33,184 & 19,066 & 14,079 & 0 & 2649 & 63,680 \\
\hline & Battery & 97,050 & 41,850 & 179,018 & 0 & 4642 & 313,276 \\
\hline & Biogas generator & 168,000 & 80,195 & 96,115 & 302,591 & 16,249 & 630,652 \\
\hline & Complete HRES & 710,134 & 374,083 & 289,212 & 302,591 & 23,540 & $1,652,480$ \\
\hline \multirow{6}{*}{ Conf-4 } & Wind turbine & 217,622 & 127,373 & 0 & 0 & 0 & 344,995 \\
\hline & PV-PCM & 89,600 & 72,617 & 0 & 0 & 0 & 162,217 \\
\hline & Converter and control panel & 30,585 & 17,573 & 14,079 & 0 & 2442 & 59,795 \\
\hline & Battery & 98,400 & 43,191 & 182,354 & 0 & 4832 & 319,113 \\
\hline & Biogas generator & 168,000 & 68,412 & 80,974 & 261,156 & 27,165 & 551,377 \\
\hline & Complete HRES & 604,207 & 329,166 & 277,407 & 261,156 & 34,439 & $1,437,497$ \\
\hline
\end{tabular}

\section{Sensitive Analysis}

A sensitive analysis of the hybrid renewable energy system has been carried out for configuration 4 to understand how variations in the costs of different components affect the net present cost and the overall cost of energy.

\subsection{Variation in PV-PCM Panel Cost}

The NPC and CoE of the hybrid system have been evaluated via variations in the PV-PCM's cost, equating to a factor of 0.8 to 1.3 of its principal cost. The variations in the NPC and CoE with changes in PV-PCM cost are shown in Figure 11. It can be observed that with changes in the cost of the PV-PCM panel, there are variations in the NPC and CoE of the system. With a $20 \%$ decrease in the cost of the PV-PCM system, the NPC and CoE of the overall system will reduce to USD 1.41 million and USD $0.093 / \mathrm{kWh}$, respectively. Similarly, with a $20 \%$ increase in PV-PCM cost, the NPC and CoE of the HRES increase to USD 1.46 and USD 0.095/kWh, respectively.

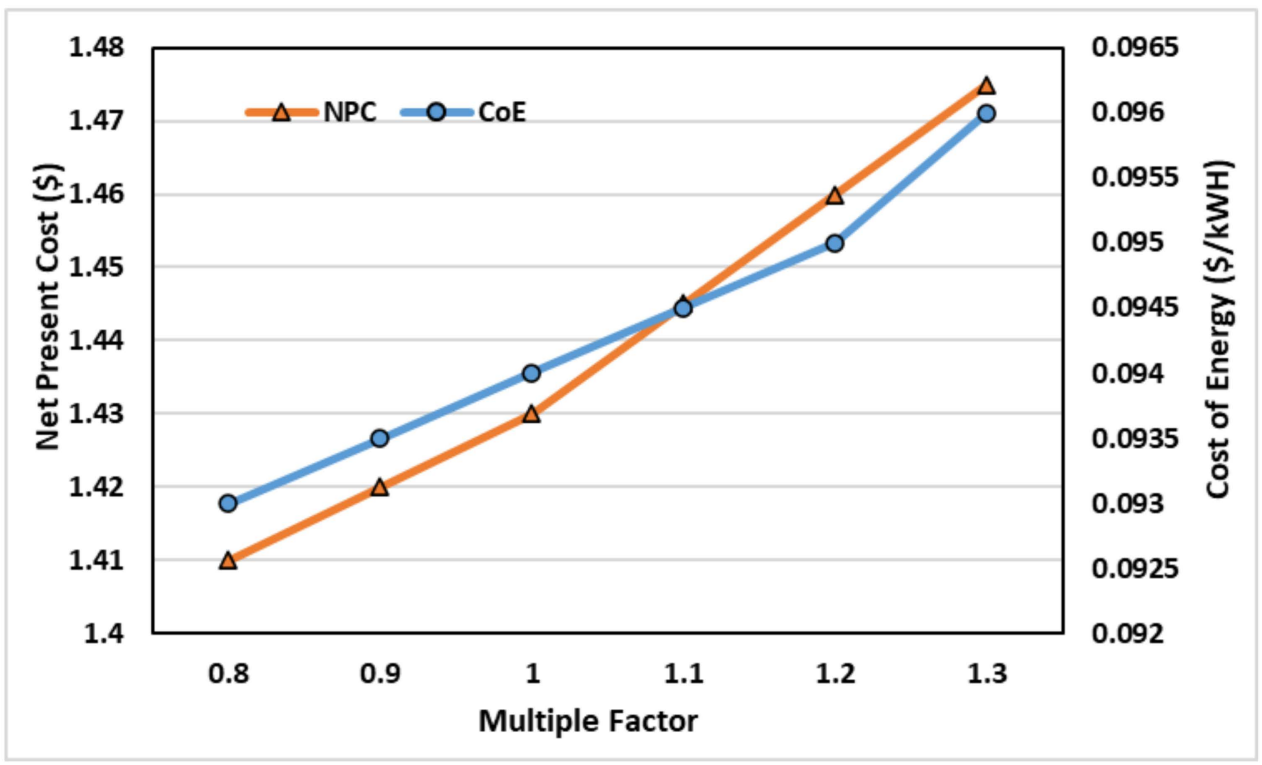

Figure 11. NPC and CoE of HRES with variation in PV-PCM cost. 


\subsection{Variation in Wind Turbine Cost}

The NPC and CoE of the hybrid system have been evaluated via the variations in the wind turbine cost, which equate to a factor of 0.8 to 1.3 of its principal cost. The variations in the NPC and CoE with changes in wind turbine cost are shown in Figure 12. It can be observed that with a change in the cost of the wind turbine, there are variations in the NPC and CoE of the system. With a $20 \%$ decrease in the cost of the wind turbine, the NPC and CoE of the overall system will reduce to USD 1.39 million and USD 0.092/kWh, respectively. Similarly, with a $20 \%$ increase in the wind turbine cost, the NPC and CoE of the HRES increase to USD 1.46 and USD 0.096/kWh, respectively.

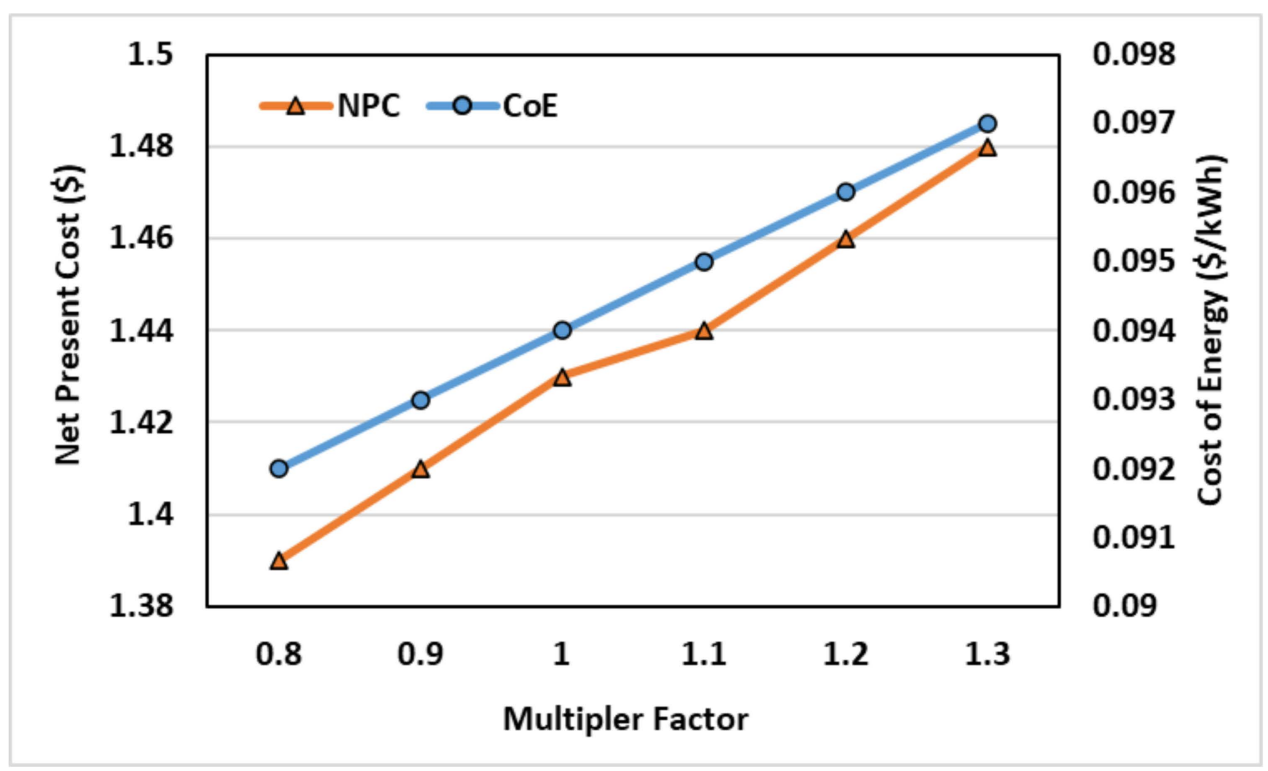

Figure 12. NPC and CoE of HRES with variations in wind turbine cost.

\subsection{Variation in Biogas Generator Cost}

The NPC and CoE of the hybrid system have been evaluated via the variations in the cost of the biogas generator, which equate to a factor of 0.8 to 1.3 of its principal cost. The variations in the NPC and CoE with changes in the cost of the biogas generator are shown in Figure 13. It can be observed that with changes in the cost of the biogas generator, there are significant variations in the NPC and CoE of the system. With a $20 \%$ decrease in the cost of the biogas generator, the NPC and $\mathrm{CoE}$ of the overall system will reduce to USD 1.37 million and USD $0.088 / \mathrm{kWh}$, respectively. Similarly, with a $20 \%$ increase in the biogas generator cost, the NPC and CoE of the HRES increase to USD 1.48 and USD 0.0975/kWh, respectively. 


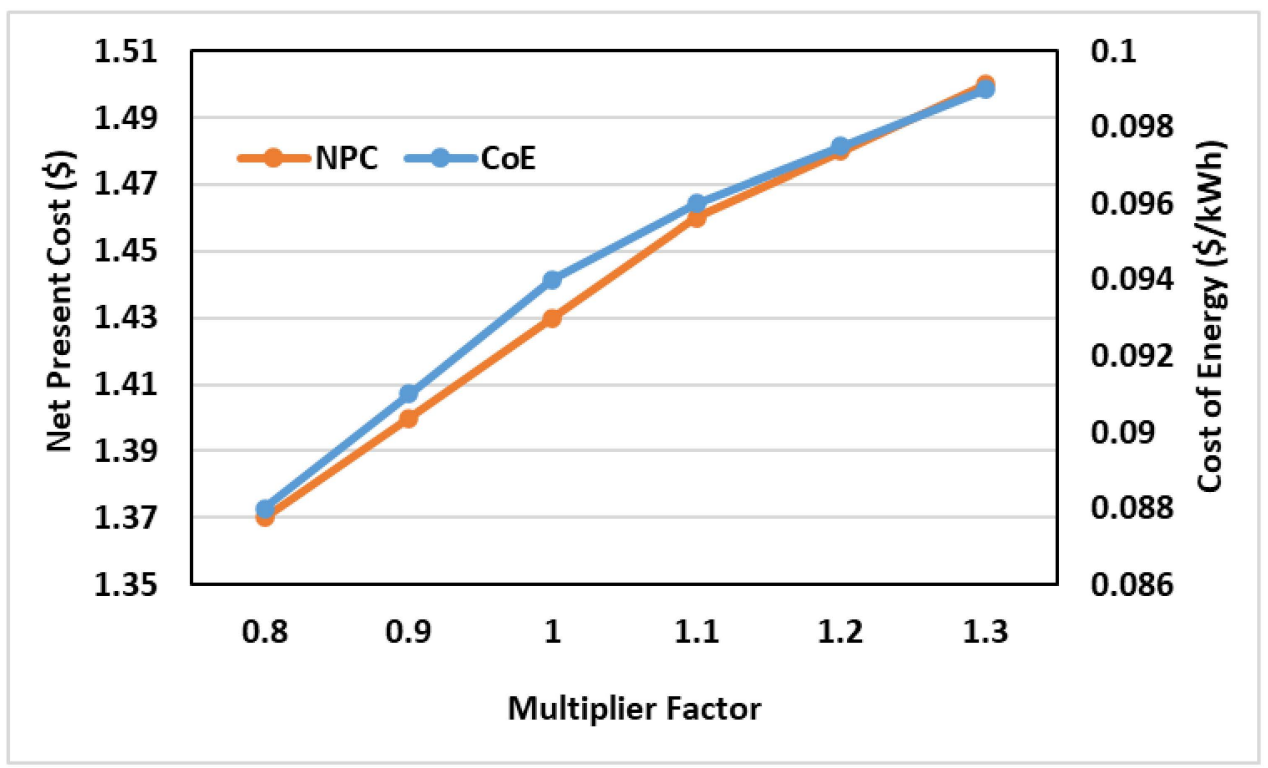

Figure 13. NPC and CoE of HRES with variation in biogas generator cost.

\subsection{Variation in Battery Cost}

The NPC and CoE of the hybrid system have been evaluated via the variations in the battery cost, which equate to a factor of 0.8 to 1.3 of its principal cost. The variations in the NPC and CoE with changes in the battery cost are shown in Figure 14. It can be observed that with a change in the battery cost, there are variations in the NPC and CoE of the system. With a 20\% decrease in the battery cost, the NPC and CoE of the overall system will reduce to USD 1.41 million and USD 0.090/kWh, respectively. Similarly, with a 20\% increase in the battery cost, the NPC and CoE of the HRES increase to USD 1.45 million and USD 0.096/kWh, respectively.

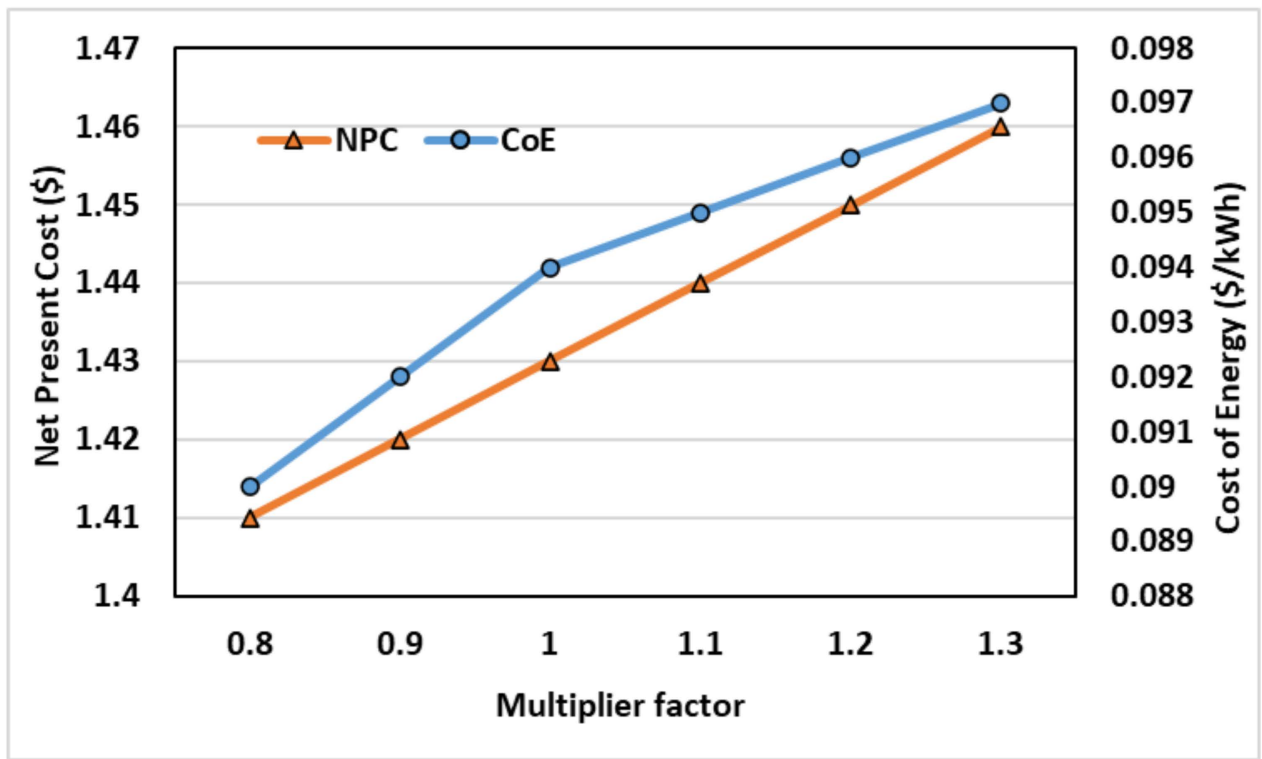

Figure 14. NPC and CoE of HRES with variations in battery cost.

\section{Conclusions}

A hybrid energy system usually consists of two or more renewable energy sources used together to provide increased system efficiency. For uninterruptible and viable power supply, various cost effective energy sources, such as solar, wind, hydro, and biogas, can be 
integrated together to meet the electric load demand in a reliable manner. There are various advantages to a hybrid renewable energy system (HRES): (i) better utilization of renewable energy, (ii) better load matching, (iii) better controllability, and (iv) lower operational and maintenance cost.

In the present study, the performance of a hybrid renewable energy system consisting of PV, PCM, a biogas generator, wind and battery has been investigated. It can be observed that due to the ability of the PCM to absorb the heat from the photovoltaic panel, the performance of the PV panel increases, which results in a reduction in the net present cost and the cost of energy of the overall system. For the PV-Wind-Biogas generator-Batterybased off-grid system, the integration of a phase change material with a PV panel results in a saving of USD 0.22 million in terms of net present cost, and reduces the cost of the energy of the system from USD $0.099 / \mathrm{kWh}$ to USD $0.094 / \mathrm{kWh}$. Similarly, for another off-grid HRES configuration of PV-Wind-Battery, the integration of a phase change material with the photovoltaic panels results in a saving of USD 0.17 million, and also reduces the cost of energy of the system from USD $0.12 / \mathrm{kWh}$ to USD $0.105 / \mathrm{kWh}$.

The present work can be expanded by integrating the PV-PCM with other renewable energy systems for different geographical locations. The PCM-based energy system can also be integrated with a cogeneration energy system for enhanced system efficiency and a lower cost of energy.

Author Contributions: Conceptualization, V.M., P.S., S.K., C.P., V.B., T.K.M., K.S.R.; methodology, V.M., P.S., S.K., C.P., V.B., T.K.M., K.S.R.; formal analysis, V.M., P.S., S.K., C.P., V.B., T.K.M., K.S.R.; investigation, V.M., P.S., S.K., C.P., V.B., T.K.M., K.S.R.; writing-original draft preparation, V.M., P.S., C.P.; writing-review and editing, V.M., P.S., S.K., C.P., V.B., T.K.M., K.S.R.; supervision, S.K., V.B., T.K.M., K.S.R.; project administration, S.K., V.B., T.K.M., K.S.R.; funding acquisition, S.K., V.B., T.K.M., K.S.R. All authors have read and agreed to the published version of the manuscript.

Funding: This research received no external funding.

Institutional Review Board Statement: Not applicable.

Informed Consent Statement: Not applicable.

Data Availability Statement: Data can be made available on request to corresponding author.

Conflicts of Interest: The authors declare no conflict of interest.

\section{References}

1. UN. United nations-sustainable energy for all initiative launched in 2011. Available online: https://www.seforall.org/goal-7targets/access (accessed on 2 October 2021).

2. Al Siyabi, I.; Al Mayasi, A.; Al Shukaili, A.; Khanna, S. Effect of Soiling on Solar Photovoltaic Performance under Desert Climatic Conditions. Energies 2021, 14, 659. [CrossRef]

3. Duran, D.C.; Gogan, L.M.; Artene, A.; Duran, V. The Components of Sustainable Development-A Possible Approach. Procedia Econ. Financ. 2015, 26, 806-811. [CrossRef]

4. Tito, S.R.; Lie, T.T.; Anderson, T.N. Optimal sizing of a wind-photovoltaic-battery hybrid renewable energy system considering socio-demographic factors. Sol. Energy 2016, 136, 525-532. [CrossRef]

5. Jamshidi, S.; Pourhossein, K.; Asadi, M. Size estimation of wind/solar hybrid renewable energy systems without detailed wind and irradiation data: A feasibility study. Energy Convers. Manag. 2021, 234, 113905. [CrossRef]

6. Alberizzi, J.C.; Frigola, J.M.; Rossi, M.; Renzi, M. Optimal sizing of a Hybrid Renewable Energy System: Importance of data selection with highly variable renewable energy sources. Energy Convers. Manag. 2020, 223, 113303. [CrossRef]

7. Martín-Arroyo, S.; Cebollero, J.A.; García-Gracia, M.; Llamazares, Á. Stand-Alone Hybrid Power Plant Based on SiC Solar PV and Wind Inverters with Smart Spinning Reserve Management. Electronics 2021, 10, 796. [CrossRef]

8. Das, M.; Singh, M.A.K.; Biswas, A. Techno-economic optimization of an off-grid hybrid renewable energy system using metaheuristic optimization approaches-Case of a radio transmitter station in India. Energy Convers. Manag. 2019, 185, 339-352. [CrossRef]

9. Rezzouk, H.; Mellit, A. Feasibility study and sensitivity analysis of a stand-alone photovoltaic-diesel-battery hybrid energy system in the north of Algeria. Renew. Sustain. Energy Rev. 2015, 43, 1134-1150. [CrossRef]

10. Rahman, M.; Hasan, M.M.; Paatero, J.; Lahdelma, R. Hybrid application of biogas and solar resources to fulfill household energy needs: A potentially viable option in rural areas of developing countries. Renew. Energy 2014, 68, 35-45. [CrossRef] 
11. Mokhtara, C.; Negrou, B.; Settou, N.; Settou, B.; Samy, M.M. Design optimization of off-grid Hybrid Renewable Energy Systems considering the effects of building energy performance and climate change: Case study of Algeria. Energy 2020, $219,119605$. [CrossRef]

12. Baruah, A.; Basu, M.; Amuley, D. Modeling of an autonomous hybrid renewable energy system for electrification of a township: A case study for Sikkim, India. Renew. Sustain. Energy Rev. 2020, 135, 110158. [CrossRef]

13. Al-Bonsrulah, H.; Alshukri, M.; Mikhaeel, L.; Al-Sawaf, N.; Nesrine, K.; Reddy, M.; Zaghib, K. Design and Simulation Studies of Hybrid Power Systems Based on Photovoltaic, Wind, Electrolyzer, and PEM Fuel Cells. Energies 2021, 14, 2643. [CrossRef]

14. Katsivelakis, M.; Bargiotas, D.; Daskalopulu, A.; Panapakidis, I.; Tsoukalas, L. Techno-Economic Analysis of a Stand-Alone Hybrid System: Application in Donoussa Island, Greece. Energies 2021, 14, 1868. [CrossRef]

15. Kanase-Patil, A.; Saini, R.; Sharma, M. Integrated renewable energy systems for off grid rural electrification of remote area. Renew. Energy 2010, 35, 1342-1349. [CrossRef]

16. Elavarasan, R.M.; Leoponraj, S.; Dheeraj, A.; Irfan, M.; Sundar, G.G.; Mahesh, G. PV-Diesel-Hydrogen fuel cell based grid connected configurations for an institutional building using BWM framework and cost optimization algorithm. Sustain. Energy Technol. Assess. 2021, 43, 100934. [CrossRef]

17. Kumar, N.; Chopra, S.; Chand, A.; Elavarasan, R.; Shafiullah, G. Hybrid Renewable Energy Microgrid for a Residential Community: A Techno-Economic and Environmental Perspective in the Context of the SDG7. Sustainability 2020, $12,3944$. [CrossRef]

18. Li, C.; Ge, X.; Zheng, Y.; Xu, C.; Ren, Y.; Song, C.; Yang, C. Techno-economic feasibility study of autonomous hybrid wind/PV/battery power system for a household in Urumqi, China. Energy 2013, 55, 263-272. [CrossRef]

19. Wu, Q.; Zhou, J.; Liu, S.; Yang, X.; Ren, H. Multi-objective Optimization of Integrated Renewable Energy System Considering Economics and $\mathrm{CO}_{2}$ Emissions. Energy Procedia 2016, 104, 15-20. [CrossRef]

20. Suleman, F.; Dincer, I.; Agelin-Chaab, M. Development of an integrated renewable energy system for multigeneration. Energy 2014, 78, 196-204. [CrossRef]

21. Chang, P.-L.; Hsu, C.-W.; Hsiung, C.-M.; Lin, C.-Y. Constructing an innovative Bio-Hydrogen Integrated Renewable Energy System. Int. J. Hydrogen Energy 2013, 38, 15660-15669. [CrossRef]

22. Karthick, A.; Murugavel, K.K.; Ramanan, P. Performance enhancement of a building-integrated photovoltaic module using phase change material. Energy 2018, 142, 803-812. [CrossRef]

23. Stropnik, R.; Stritih, U. Increasing the efficiency of PV panel with the use of PCM. Renew. Energy 2016, 97, 671-679. [CrossRef]

24. Khanna, S.; Reddy, K.S.; Mallick, T.K. Effect of climate on electrical performance of finned phase change material integrated solar photovoltaic. Sol. Energy 2018, 174, 593-605. [CrossRef]

25. Khanna, S.; Newar, S.; Sharma, V.; Reddy, K.; Mallick, T.K. Optimization of fins fitted phase change material equipped solar photovoltaic under various working circumstances. Energy Convers. Manag. 2019, 180, 1185-1195. [CrossRef]

26. Khanna, S.; Newar, S.; Sharma, V.; Reddy, K.; Mallick, T.K.; Radulovic, J.; Khusainov, R.; Hutchinson, D.; Becerra, V. Electrical enhancement period of solar photovoltaic using phase change material. J. Clean. Prod. 2019, 221, 878-884. [CrossRef]

27. Roque, P.; Chowdhury, S.; Huan, Z. Performance Enhancement of Proposed Namaacha Wind Farm by Minimising Losses Due to the Wake Effect: A Mozambican Case Study. Energies 2021, 14, 4291. [CrossRef]

28. Chauhan, A.; Saini, R. Techno-economic optimization based approach for energy management of a stand-alone integrated renewable energy system for remote areas of India. Energy 2016, 94, 138-156. [CrossRef]

29. Klugmann-Radziemska, E.; Wcisło-Kucharek, P. Photovoltaic module temperature stabilization with the use of phase change materials. Sol. Energy 2017, 150, 538-545. [CrossRef]

30. Reddy, K.; Mudgal, V.; Mallick, T. Review of latent heat thermal energy storage for improved material stability and effective load management. J. Energy Storage 2018, 15, 205-227. [CrossRef]

31. Reddy, K.S.; Mudgal, V.; Mallick, T.K. Thermal Performance Analysis of Multi-Phase Change Material Layer-Integrated Building Roofs for Energy Efficiency in Built-Environment. Energies 2017, 10, 1367. [CrossRef]

32. Ahmad, A.; Navarro, H.; Ghosh, S.; Ding, Y.; Roy, J. Evaluation of New PCM/PV Configurations for Electrical Energy Efficiency Improvement through Thermal Management of PV Systems. Energies 2021, 14, 4130. [CrossRef]

33. Bandaru, S.; Becerra, V.; Khanna, S.; Radulovic, J.; Hutchinson, D.; Khusainov, R. A Review of Photovoltaic Thermal (PVT) Technology for Residential Applications: Performance Indicators, Progress, and Opportunities. Energies 2021, 14, 3853. [CrossRef]

34. Al Siyabi, I.; Khanna, S.; Sundaram, S.; Mallick, T. Experimental and Numerical Thermal Analysis of Multi-Layered Microchannel Heat Sink for Concentrating Photovoltaic Application. Energies 2019, 12, 122. [CrossRef]

35. Singh, P.; Khanna, S.; Becerra, V.; Newar, S.; Sharma, V.; Mallick, T.K.; Hutchinson, D.; Radulovic, J.; Khusainov, R. Power improvement of finned solar photovoltaic phase change material system. Energy 2020, 193, 116735. [CrossRef]

36. Japs, E.; Sonnenrein, G.; Steube, J.; Vrabec, J.; Kenig, E.; Krauter, S. Technical Investigation of a Photovoltaic Module with Integrated Improved Phase Change Material. In Proceedings of the 28th European photovoltaic solar energy conference and exhibition, Paris, France, 30 September-4 October 2013. [CrossRef]

37. Specification, Test Generator; Sawafuji Electric Co., Ltd. ELEMAX Generator SH7600EX: Owner's Manual; 2015. Available online: http:/ / www.elemax.jp/products_ex.html (accessed on 22 March 2021).

38. Chiasson, J.; Vairamohan, B. Estimating the State of Charge of a Battery. IEEE Trans. Control Syst. Technol. 2005, 13, 465-470. [CrossRef] 
39. Singh, A.; Baredar, P.; Gupta, B. Techno-economic feasibility analysis of hydrogen fuel cell and solar photovoltaic hybrid renewable energy system for academic research building. Energy Convers. Manag. 2017, 145, 398-414. [CrossRef]

40. Kashefi Kaviani, A.; Riahy, G.H.; Kouhsari, S.M. Optimal design of a reliable hydrogen-based stand-alone wind/PV generating system, considering component outages. Renew Energy 2009, 34, 2380-2390. [CrossRef]

41. Lian, J.; Zhang, Y.; Ma, C.; Yang, Y.; Chaima, E. A review on recent sizing methodologies of hybrid renewable energy systems. Energy Convers. Manag. 2019, 199, 112027. [CrossRef] 